\title{
Carica pubescens fruit juice reduces tumor necrosis factor-alpha (TNF- $\alpha$ ) and fasting blood glucose (FBG) levels in type 2 diabetes mellitus Wistar rats
}

\author{
${ }^{1}$ Kusuma, T.U., ${ }^{1}$ Rachmawati, S.N., ${ }^{1}$ Anjani, G. and ${ }^{2 *}$ Muniroh, M. \\ ${ }^{1}$ Department of Nutrition Science, Faculty of Medicine, Diponegoro University, Tembalang, Semarang, \\ 50275 Indonesia \\ ${ }^{2}$ Department of Physiology, Faculty of Medicine, Diponegoro University, Tembalang, Semarang, 50275 \\ Indonesia
}

\author{
Article history: \\ Received: 29 December 2019 \\ Received in revised form: 26 \\ March 2020 \\ Accepted: 18 April 2020 \\ Available Online: 30 May \\ 2020
}

Keywords:

Type 2 diabetes mellitus,

Carica pubescens,

TNF- $\alpha$,

Fasting blood glucose

DOI:

https://doi.org/10.26656/fr.2017.4(S3).S15

\begin{abstract}
Chronic inflammation and hyperglycemia in type 2 diabetes mellitus (T2DM) can cause several complications due to organ dysfunctions. Carica pubescens $(\mathrm{CP})$ is a typical fruit from Dieng Plateau, Indonesia which contains some rutin that is kind of flavonoid. It is well known that flavonoid acts as anti-inflammation and anti-hyperglycemic which is useful for T2DM conditions. This study was aimed to investigate the effect of CP fruit juice on tumor necrosis factor-alpha (TNF- $\alpha$ ) and fasting blood glucose (FBG) levels in rats induced by HFD-STZ, with rutin as a control. The design of this study was a randomized post-test only control group design. A total of twenty-five male Wistar rats were divided into 5 groups: $\mathrm{K}-=$ normal group; $\mathrm{K}+=$ diabetic group; $\mathrm{X} 1$ and $\mathrm{X} 2=$ diabetic groups that received $\mathrm{CP}$ fruit juice $4 \mathrm{~mL} / 200 \mathrm{~g} \mathrm{BW} /$ day and $8 \mathrm{~mL} / 200 \mathrm{~g} \mathrm{BW} /$ day; $\mathrm{X} 3$ = diabetic group that received rutin $10 \mathrm{~mL} / 200 \mathrm{~g} \mathrm{BW} /$ day. The treatments were administered orally for 30 days. TNF- $\alpha$ and FBG levels were measured using ELISA and GOD-PAP method respectively. The results showed that TNF- $\alpha$ and FBG levels were significantly decreased in the treatment groups (X1, X2, X3) compared with the $\mathrm{K}+$ group $(p<0,05)$. Also, there was no significant difference in TNF- $\alpha$ and FBG levels between group $\mathrm{X} 2$ and $\mathrm{X} 3$, indicating that $\mathrm{CP}$ fruit juice $8 \mathrm{~mL} / 200 \mathrm{~g} \mathrm{BW} /$ day has a similar ability with rutin $10 \mathrm{mg} / 200 \mathrm{~g} \mathrm{BW} /$ day. It can be concluded that $\mathrm{CP}$ fruit juice can be a recommended fruit juice for a diabetic condition by reducing TNF- $\alpha$ and FBG levels.
\end{abstract}

\section{Introduction}

Diabetes Mellitus (DM) is a serious and growing health problem all over the world (Frances et al., 2013). In type 2 diabetes mellitus (DMT2), there is a glucose tolerance disturbance as a result of insulin resistance and pancreatic $\beta$-cell damage (Badawi et al., 2010). According to the International Diabetes Federation (IDF), the world's DM prevalence was 463 million cases in 2019 and will continue to increase to 700 million cases in 2045. Indonesia has 10,7 million DM cases in 2019 and occupies 7th ranks as the country with the most DM patients (IDF, 2019). Type 2 diabetes mellitus (T2DM) is closely related to excessive calorie intake history which further leads to excessive body weight. In individuals who experience overweight, hypertrophy and hyperplasia occur in adipose tissue (Monteiro and Azevedo, 2010; Xu, 2013). This condition results in inadequate blood supply impacting the poor oxygenation of the tissues, which is called tissue hypoxia. Hypoxia is one of the factors that play a role in the occurrence of inflammation in adipose tissue. Such inflammation is characterized by an increase in the expression of proinflammatory cytokines, one of which is TNF- $\alpha$. TNF- $\alpha$ relates to the development of insulin resistance in T2DM patients who have excessive body weight history $(\mathrm{Xu}$, 2013).

Subsequent insulin resistance will cause impaired glucose tolerance resulting in increased hepatic glucose production and decreased glucose uptake into cells and tissues that lead to hyperglycemia condition (Ormazabal et al., 2018). Hyperglycemia condition itself can directly worsen inflammatory conditions, wherein the subsequent increase of the pro-inflammatory cytokines can lead to damage to the $\beta$-cell pancreas and endocrine malfunctions (Frances et al., 2013). Also, hyperglycemia which occurs chronically can lead to organ dysfunction such as eye, kidney, nervous system, heart, and blood vessels (ADA, 2013). Therefore, by controlling 
inflammatory and hyperglycemia conditions is expected to control the disease progression so that complications can be more prevented. Flavonoid compound which is widely contained in food is well known can improve inflammatory conditions (Panche et al., 2016).

Flavonoid is a natural compound with a variety of phenolic structures that are found in plants and beneficial to human health (Panche et al., 2016). One of the ingredients that contain flavonoid compounds and not much known and utilized by Indonesian people is Carica pubescens $(\mathrm{CP})$ fruit. C. pubescens is a typical plant in Indonesia that is found in Dieng Plateau, Indonesia (Laily and Khoiri, 2016). C. pubescens contains rutin compound (Simirgiotis et al., 2009). Rutin is a type of flavonoid that has properties as anti-inflammatory and anti-hyperglycemia. This makes $\mathrm{CP}$ fruit has the potential to control inflammation and blood glucose in T2DM (Niture, Ansari and Naik, 2014; Ghorbani, 2017).

A study conducted by Niture, Ansari and Naik (2014) proved that rats with T2DM showed a decrease in blood glucose and TNF- $\alpha$ levels after given pure rutin at a dose of 50 and $100 \mathrm{mg} / \mathrm{kg} \mathrm{BW}$ for 3 weeks. Besides rutin, $\mathrm{CP}$ rutin also contains other compounds such as quercetin, caffeic acid, chlorogenic acid and coumaric acid which have synergistic effects related to antiinflammatory and anti-hyperglycemia (Pinto et al., 2009). The research on CP fruit juice especially related to T2DM has never been studied before. This study aimed to determine the effect of CP fruit juice on TNF- $\alpha$ and fasting blood glucose levels in T2DM rats, with pure rutin as a comparator.

\section{Materials and methods}

\subsection{Material and reagent}

CP fruits were obtained from Dieng Plateau, Wonosobo, Indonesia that naturally grow at 2093 masl altitude. CP fruits used in this study were CP fruits with a $90 \%$ ripeness level ( $90 \%$ yellow peel color). Pure rutin powders were obtained from Xi'an Imaherb Biotech Co., Ltd. Streptozotocin (STZ) and nicotinamide (NA) were obtained from Nacalai Tesque, Kyoto-Japan. The TNF- $\alpha$ examination used the TNF- $\alpha$ kit Fine Test brand, China. Fasting blood glucose examination used Diasys kit, Germany.

\subsection{Animals and treatments}

This research used 25 male Wistar (Rattus Norvegicus) rats which were obtained from Central Food and Nutrition Laboratory Gajah Mada University (UGM), Yogyakarta, Indonesia with inclusion criteria: age 2 months, body weight 150-200 grams and healthy conditions with active movements. Rats were acclimatized for 7 days in individual cages at $25^{\circ} \mathrm{C}$ with a 12-hour lighting cycle and given Comfeed II 20 grams/ day as a standard feed that contains crude protein content $15 \%$, crude fat $3-7 \%$, water $12 \%$, crude fiber $6 \%$, ash $7 \%$, calcium $0.9-1.1 \%$, and phosphorus $0.6-0.9 \%$ and drinks ad libitum were administered during the period of acclimatization to the end of the study. High-fat diet (HFD) was administered for 14 days after the period of acclimatization at $20 \mathrm{~g} / \mathrm{rats} / \mathrm{day}$, with the composition of com feed II $90 \%$, pork fat $10 \%$, and pure cholesterol was $1.25 \%$. On the $22^{\text {nd }}$ day, rats were intraperitoneally induced with NA $110 \mathrm{mg} / \mathrm{kg} \mathrm{BW}$ (dissolved with $\mathrm{NaCl}$ $1.5 \mathrm{~mL} / 100 \mathrm{~g} \mathrm{BW}$ ) and STZ $45 \mathrm{mg} / \mathrm{kg} \mathrm{BW}$ (dissolved with sodium citrate buffer $1.5 \mathrm{~mL} / 100 \mathrm{~g}$ BW) 15 mins after the induction of NA, and three days later the fasting blood glucose levels were examined. Rats have fasted for 6-8 hrs first and then their blood was taken $2 \mathrm{~mL}$ through the plexus retroorbital. Rats were declared to have DMT2 when having blood glucose levels $>200 \mathrm{mg} / \mathrm{dl}$ (Ghasemi et al., 2014). Rat's body weight was measured every 7 days during the acclimatization and HFD administration, and every 3 days during the intervention period.

The design of this study was randomized post-test only control group design. After acclimatization period, rats were divided into two groups: None-HFD (5 rats) as the negative control group (K-), and HFD (20 rats) group that was induced by STZ/NA and divided into 4 groups: diabetic control group $(\mathrm{K}+)$; diabetic + Karika fruit juice $4 \mathrm{~mL} / 200 \mathrm{~g}$ BW/day (X1); diabetic + Karika fruit juice 8 $\mathrm{mL} / 200 \mathrm{~g} \mathrm{BW} /$ day (X2); diabetic + rutin $10 \mathrm{mg} / 200 \mathrm{~g}$ $\mathrm{BW} /$ days (X3). All treatments were orally administered for 30 days. About $2 \mathrm{~mL}$ of blood was collected through plexus retroorbital after rats were fasted for 6-8 hours, and centrifuged at $4000 \mathrm{rpm}$ for 15 minutes to obtain the blood serum to used for examination of TNF- $\alpha$ and final fasting blood glucose levels.

We used rutin as a flavonoid control, that we assumed contain in CP fruit. Based on previous studies, rutin at a dose of $50 \mathrm{mg} / \mathrm{kg}$ of $\mathrm{BW}$ or $10 \mathrm{mg} / 200 \mathrm{~g}$ of BW may decrease the condition of hyperglycemia in diabetic rats (Niture, Ansari and Naik, 2014). The rutin used in this study was a rutin extract which was obtained from Flo's plant Sophorae Immaturus and was purchased from Xi'an Imaherb Biotech Co., Ltd. Rutin is powdershaped and dissolved in aquadest to be administered to rats (X3 Group) orally once per day for 30 days.

\subsection{The preparation of $C P$ fruit juice}

First of all, CP fruits were peeled and deseeded and then washed thoroughly. Then the fruit is cut into small pieces and rinsed with saltwater. Then the fruit was blanched for 3 mins at $60^{\circ} \mathrm{C}$. The purpose of rinsing with 
saltwater and blanching is was to remove the sap found in the fruit. The sap is itchy and bitter, therefore blanching was also done to make the texture of the flesh soft (Adinugraha et al., 2018; Yusmita and Wijayanti, 2018). Furthermore, a total of $100 \mathrm{~g}$ of $\mathrm{CP}$ fruit was then processed into juice using blender and homogenizer.

\subsection{Determination of rutin content in CP fruit juice}

Pure rutin of $50 \mathrm{~g}$ was dissolved in $50 \mathrm{~mL}$ of ethanol to get a stock solution with a concentration of $1000 \mathrm{ppm}$. Then the stock solution was diluted with ethanol to get various concentrations of standard solutions ranging from $0-50 \mathrm{ppm} .2 \mathrm{~mL}$ of each standard solution was taken and transferred into a cuvette, then the absorbance was measured with a spectrophotometer at a wavelength of $359 \mathrm{~nm}$.

$\mathrm{CP}$ fruit juice was dissolved in an ethanol solvent with a ratio of 1:1 and mixed using a vortex. Then the solution was centrifuged at $4500 \mathrm{rpm}$ for 15 mins and 2 $\mathrm{mL}$ of supernatant was taken and transferred into a cuvette. The absorbance was measured with a spectrophotometer at a wavelength of $359 \mathrm{~nm}$.

\subsection{The Examination of TNF- $\alpha$ levels}

The examination of TNF- $\alpha$ levels was measured by sandwich Enzyme-Linked Immunosorbent Assay (ELISA) method. Plates were washed two times before adding standard, sample (rats blood serum) and control (blank) wells. Standard or sample $(100 \mu \mathrm{L})$ were added to each well and were incubated for 90 minutes at $37^{\circ} \mathrm{C}$. Plates were aspirated and washed two times. A $100 \mu \mathrm{L}$ Biotin-labeled antibody working solution was added to each well and incubated for $60 \mathrm{mins}$ at $37^{\circ} \mathrm{C}$. Plates were aspirated and washed three times. A $100 \mu \mathrm{L}$ SABC Working Solution was added into each well and incubated for 30 minutes at $37^{\circ} \mathrm{C}$. Plates were aspired and washed five times. A total of $90 \mu \mathrm{L}$ TMB Substrate was added and incubated for $30 \mathrm{mins}$ at $37^{\circ} \mathrm{C}$. Stop solution of $50 \mu \mathrm{L}$ were added in the final process. The absorbance was measured at a wavelength of $450 \mathrm{~nm}$ immediately.

\subsection{The Examination of fasting blood glucose levels}

The examination of fasting blood glucose levels was done by Glucose Oxidase Phenol 4-AminoPhenazone (GOD-PAP) method. As many as 27 tubes were prepared, with details: 25 tubes containing $10 \mu \mathrm{L}$ samples (rat blood serum), 1 tube containing a $10 \mu \mathrm{L}$ standard solution and 1 tube containing $10 \mu \mathrm{L}$ blank (aquadest). Each $1000 \mu \mathrm{l}$ of reagent was added into the 27 tubes. The solution was mixed using a vortex and then was incubated for $20 \mathrm{mins}$ at $20-25^{\circ} \mathrm{C}$. The absorbance was measured using a spectrophotometer at a wavelength of $500 \mathrm{~nm}$. Blood glucose levels were calculated with the following formula:

Blood glucose level $(\mathrm{mg} / \mathrm{dL})=\frac{\text { Sample absorbance } \times \text { standard concentration }}{\text { Standard absorbance }}$

\subsection{Statistical analysis}

The data of this study were analyzed statistically with a significance value $\mathrm{p}<0.05$ and CI $95 \%$. The differences between TNF- $\alpha$ and fasting blood glucose levels were analyzed using the One-Way ANOVA Test and followed by Bonferroni's Post-Hoc test because the data were normally distributed.

\subsection{Ethical clearance}

This research has obtained the Ethical Clearance approval from the Health Research Ethics Committee (KEPK), Faculty of Medicine Diponegoro University Semarang No.14/EC/H/FK-UNDIP/II/2019.

\section{Results}

\subsection{Rutin content in CP fruit juice}

The Rutin content of CP fruit in this study was 13.63 $\mu \mathrm{g} / \mathrm{g}$ fresh weight or $13.87 \mu \mathrm{g} / \mathrm{mL}$ (in the form of juice). This result is lower than the previous study conducted by Simirgiotis et al (2009) where the rutin content in CP fruit in that study was $31 \mu \mathrm{g} / \mathrm{g}$ fresh weight.

\subsection{The effect of CP fruit juice and rutin on TNF- $\alpha$ levels}

TNF- $\alpha$ levels were measured after rats were given CP fruit juice and rutin for 30 days. Based on Figure 1, there were significant differences in TNF- $\alpha$ levels in the treatment groups between before and after the administration of $\mathrm{CP}$ fruit juice and rutin $(\mathrm{p}<0.05)$ in which the group received rutin (X3) had the lowest TNF$\alpha$ level. TNF- $\alpha$ levels in the group that received CP fruit juice $8 \mathrm{~mL} / 200 \mathrm{~g} \mathrm{BW} /$ day (X2) was lower than and significantly differed when compared with the group that received CP fruit juice $4 \mathrm{~mL} / 200 \mathrm{~g} \mathrm{BW} /$ day $(\mathrm{p}=0.000$ ). Figure 1 also shows that there were no significant differences in the TNF- $\alpha$ levels between the healthy rat group (K-) with group $\mathrm{X} 3(\mathrm{p}=0.113)$. Also, the TNF- $\alpha$ levels did not differ significantly between the $\mathrm{X} 2$ and $\mathrm{X} 3$ groups $(\mathrm{p}=1.000)$.

\subsection{The effect of CP fruit juice and rutin on fasting blood glucose levels}

Final fasting blood glucose levels were measured after rats were given CP fruit juice and rutin for 30 days. Figure 2 shows the comparison of fasting blood glucose levels between groups after intervention. There were significant differences in rats fasting blood glucose levels in the treatment groups between before and after 


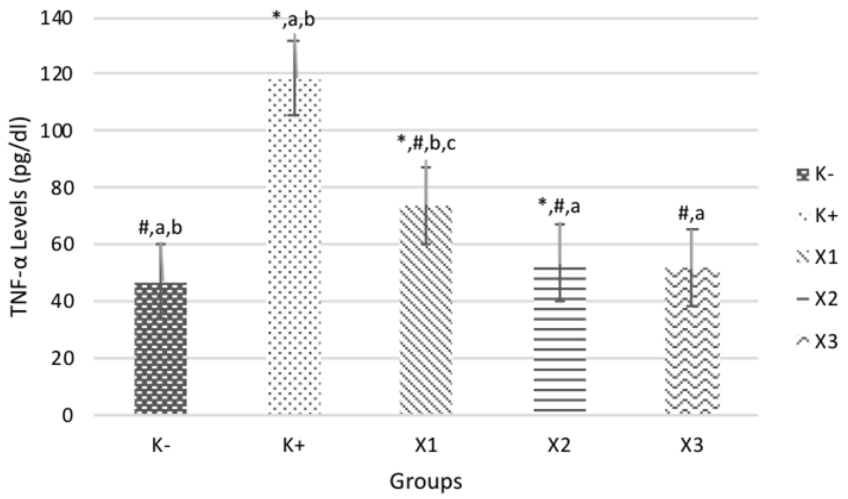

Figure 1. TNF- $\alpha$ Levels after CP Fruit Juice and Rutin administration in T2DM Wistar Rats

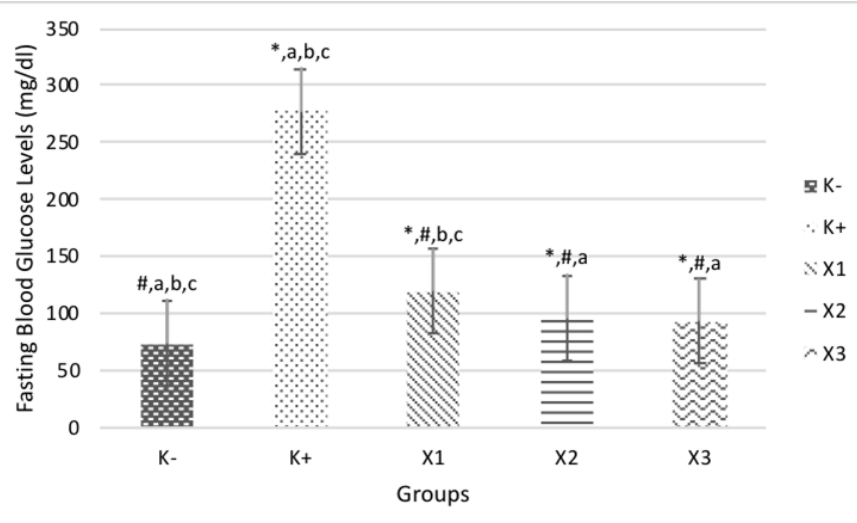

Figure 2. Fasting Blood Glucose Levels after CP Fruit Juice and Rutin administration in T2DM Wistar Rats

$\mathrm{K}-=$ normal group; $\mathrm{K}+=$ diabetic group; $\mathrm{X} 1$ and $\mathrm{X} 2=$ diabetic groups that received $\mathrm{CP}$ fruit juice $4 \mathrm{~mL} / 200 \mathrm{~g} \mathrm{BW} /$ day and 8 $\mathrm{m} / 200 \mathrm{~g} \mathrm{BW} /$ day; X3 = diabetic group that received rutin $10 \mathrm{~mL} / 200 \mathrm{~g} \mathrm{BW} /$ day. Statistical analysis was measured using One Way ANOVA test and followed by Bonferroni's Post hoc test. ${ }^{*}$ Compared with $\mathrm{K}-; \mathrm{p}<0.05$; ${ }^{*}$ compared with $\mathrm{K}+; \mathrm{p}<0.05$; ${ }^{a}$ compared with X1; $<0.05 ;{ }^{b}$ compared with X2; $<0.05$; ${ }^{c}$ compared with X3; $<<0.05$.

the administration of $\mathrm{CP}$ fruit juice and rutin $(\mathrm{p}<0.05)$ in which the group that received rutin (X3) had the lowest fasting blood glucose levels. Fasting blood glucose levels in the group that received CP fruit juice $8 \mathrm{~mL} / 200 \mathrm{~g} \mathrm{BW} /$ day (X2) was lower than and significantly differed when compared with the group that received Carica juice 4 $\mathrm{mL} / 200 \mathrm{~g} \mathrm{BW} /$ day $(\mathrm{X} 1)(\mathrm{p}=0.000)$. Figure 2 also shows that there was no significant difference in fasting blood glucose levels between the X2 and X3 groups ( $p=1.000)$.

\section{Discussion}

The differences in rutin content in CP fruit can be caused by several factors, one of which is environmental factors due to differences in the growth area. CP fruits used in this study were obtained from the Dieng Plateau region, Indonesia, while the $\mathrm{CP}$ fruits in the previous study were from the Chile region (Simirgiotis et al., 2009). According to the research conducted by Liu et al (2016), the higher air temperature has an impact on the lower rutin content. Also, the length of sunlight is directly proportional to the rutin content, while rainfall is negatively correlated with rutin content (Liu et al., 2016). Dieng plateau area has an average temperature of around $15^{\circ} \mathrm{C}$, while Chile is at $13.6^{\circ} \mathrm{C}$. The average sunlight duration in Dieng is $<300$ hours/year, while in Chile $>300$ hours/year. The average rainfall in the Dieng area is $2500 \mathrm{~mm} /$ year, while in Chile it is $733 \mathrm{~mm} /$ year. Based on the comparison of air temperature, rainfall, and duration of sunlight between Dieng and Chile regions above, it can be concluded that the Dieng region has higher temperatures and rainfall, and lower sunlight duration compared to the Chilean region. This was assumed to affect the rutin content contained in CP fruit in this study, where the value was lower than in previous study (Rusiah et al., 2005; Stolpe and Undurraga, 2016). Also, the lower rutin content of CP fruit in this study compared to previous studies was assumed to be caused by the homogenization of the sample which was still lacking when testing so that its solubility in the solvent was less than optimal. Solubility is defined as the interaction of two or more substances to form a homogeneous molecular disperse. Solubility is related to the particle size of a sample. The greater the surface area of the sample, the greater the interaction with the solvent, so that its solubility will increase. In this study, the homogenization of the sample, CP fruit, was carried out by blending CP fruits. However, when mixed with solvents there was still a small amount of CP fruits deposits at the bottom of the tube (Kumar and Singh, 2016).

The improvement of TNF- $\alpha$ levels in the group that received $\mathrm{CP}$ fruit juice is presumed to be caused by the content of various compounds in CP fruit juice, which can act as an anti-inflammatory. CP fruit juice contains a rutin compound (Simirgiotis, 2009). In addition to those compounds, according to Pinto et al. (2009), CP fruit also contains quercetin, caffeic acid, chlorogenic acid, and coumaric acid compounds. Rutin, quercetin, caffeic acid, chlorogenic acid and coumaric acid in CP fruit juice work synergistically in controlling inflammatory conditions in T2DM. Rutin and caffeic acid can inhibit the expression of pro-inflammatory cytokine genes, such as TNF- $\alpha$, which will then reduce its production so that the TNF- $\alpha$ levels decreased (Yang et al., 2013; Niture, Ansari and Naik, 2014). Rutin is also able to reduce the formation of AGEs in diabetes mellitus condition. The high levels of blood glucose that occur chronically can cause glucotoxicity in pancreatic $\beta$-cells. Glutotoxicity enhances the occurrence of oxidative stress and accumulation of AGEs. Accumulated AGEs can stimulate the increase of pro-inflammatory cytokines and cell death which then underpins the occurrence of 
diabetes complications (Liang et al., 2018; Volpe et al., 2018).

Quercetin, chlorogenic acid and coumaric acid compounds in $\mathrm{CP}$ fruit juice improve inflammatory conditions through the NF-kB pathway. NF-kB is a complex protein that plays a key role in DNA transcription, cytokine production, and also cell survival (Chen et al., 2016; Liang and Kitts., 2016; Zhao et al., 2016; Yahfoufi et al., 2018). The history of excessive calorie intake and chronic hyperglycemia in T2DM can increase the production of ROS and AGEs. This will then initiate the production of pro-inflammatory cytokines through the activation of the NF-kB pathway. The NF-kB protein was initially inactive because it was tied to IkB in the cytoplasm. The existence of the excessive production of ROS will activate the IKK which further phosphorylating IkB. Phosphorylation of $\mathrm{IkB}$ causes protein degradation of IkB itself with the help of proteasome and resulted in the release of NF-kB. NF$\mathrm{kB}$ then translocates into the nucleus and enhances the expression of several genes, including the proinflammatory cytokine genes, one of which is TNF- $\alpha$ (Gonzalez et al., 2012; Suryavanshi and Kulkarni, 2017; Chen et al., 2018).

Besides through the NF-kB pathway, a coumaric acid compound in CP fruit juice is also able to decrease TNF- $\alpha$ levels via the MAPK pathway (Zhao et al., 2016; Suryacanshi and Kulkarni, 2017). MAPK is a series of proteins in the cells involved in cell communication. The MAPK pathway plays an important role in signaling the communication of receptors on the cell surface to DNA within the cell nucleus to regulate several cellular functions such as cell proliferation, growth, differentiation, migration, and death. Bonds between several factors with number receptors on the cell surface result in signal transduction and activation of gene expression and then end this signal as negative feedback (Manzoor and Koh, 2012). The stimulus from the outside of cells, such as oxidative stress, stimulates MAPKKK to phosphorylate and activate MAPKK. The activated MAPKK then phosphorylates and activates MAPK. Furthermore, the activated MAPK phosphorylates some transcription factors, thereby causing an increase in the expression of pro-inflammatory cytokine genes, one of which is TNF- $\alpha$ (Chen et al., 2018). Also, a decrease in TNF- $\alpha$ levels occurs in a group that received rutin 10 $\mathrm{mg} / 200 \mathrm{~g} \mathrm{BW} /$ day for 30 days (X3). The results of this study were supported by previous studies stating that rutin administration at a dose of 50 and $100 \mathrm{mg} / \mathrm{kg} \mathrm{BW}$ for 21 days may significantly reduce TNF- $\alpha$ levels in diabetic rats (Volpe et al., 2018).

TNF- $\alpha$ levels in the rutin group were not significantly different compared with the negative control group. It indicates that the administration of rutin $10 \mathrm{mg} / 200 \mathrm{~g} \mathrm{BW} /$ day for 30 days in T2DM rats may decrease TNF- $\alpha$ levels equivalent to the normal group. Also, TNF- $\alpha$ levels were not significantly differed between $\mathrm{X} 2$ and $\mathrm{X} 3$ groups. These results indicate that CP fruit juice $8 \mathrm{~mL} / 200 \mathrm{~g} \mathrm{BW} /$ day has a similar ability with rutin $10 \mathrm{mg} / 200 \mathrm{~g} \mathrm{BB} /$ day in lowering TNF- $\alpha$ levels in T2DM rats. It is presumed because CP fruit juice does not only contain rutin compounds, but also other compounds, such as quercetin, caffeic acid, chlorogenic acid and coumaric acid (Pinto et al., 2009). These compounds work synergistically as anti-inflammatory so they can match the rutin ability to reduce TNF- $\alpha$ levels in T2DM. On the other hand, the high levels of TNF- $\alpha$ in the $\mathrm{K}+$ group at the end of this research is due to the chronic hyperglycemia condition that occurs due to the administration of HFD and STZ without being accompanied by remedial efforts. Hyperglycemia itself then increases the levels of pro-inflammatory cytokines, one of which is TNF- $\alpha$, through increased macrophages stimulation, oxidative stress and AGEs formation (Giri et al., 2018).

The results of this study also show that $\mathrm{CP}$ fruit juice can decrease fasting blood glucose levels in T2DM rats. The improvement of blood glucose levels in the group that received $\mathrm{CP}$ fruit juice is presumed to be caused by the content of various compounds in $\mathrm{CP}$ fruit juice, which can act as an anti-hyperglycemia. CP fruit contains a rutin compound. Besides rutin, according to Pinto et al. (2009), CP fruit also contains quercetin, caffeic acids, chlorogenic acid and coumaric acid (Pinto et al., 2009). Rutin, caffeic acid and chlorogenic acid in $\mathrm{CP}$ fruit juice are presumed to be lowering blood glucose levels through several mechanisms. Firstly, these compounds can reduce glucose absorption in the small intestine by inhibiting $\alpha$-amylase and $\alpha$-glucosidase enzymes. The $\alpha$-glucosidase enzyme is a membranebound enzyme located in the small intestinal epithelium that catalyzes glucose breakdown from disaccharides into monosaccharides. Inhibition of glucose absorption from the colon can prevent the occurrence of increased blood glucose levels sharply. Secondly, those compounds can regenerate the pancreatic $\beta$-cell damage and protect pancreatic $\beta$-cell from glucotoxicity so that insulin secretion and glucose uptake can be increased (Matsuda and Shinomira, 2013; Meng et al., 2013; Niture et al., 2014; Dhungyal et al., 2014; Volpe et al., 2018).

Also, rutin, quercetin, and caffeic acid can increase GLUT-4 translocation so that glucose uptake into the cell can be increased (Niture et al., 2014; Dhungyal et al., 2014; Mukhopadhyay and Prajapati, 2015). Then the 
increase in gluconeogenesis is believed to be one of the causes of hyperglycemia in diabetes. Rutin and coumaric acid in CP fruit juice are known to reduce gluconeogenesis by decreasing the activity glucose-6phosphatase and fructose-1.6-bisphosphatase enzymes as well as increasing the activity of hexokinase enzyme (Niture et al., 2014; Shairibha et al., 2014, Amalan et al., 2015). Quercetin and caffeic acid also act as antihyperglycemic by increasing the activity of glucokinase enzyme in the liver so that the glucose storage in the liver increases and the production of hepatic glucose decreases (Dhungyal et al., 2014; Mukhopadhyay and Prajapati, 2015). Improved fasting blood glucose levels also occur in the diabetic with rutin $10 \mathrm{mg} / 200 \mathrm{~g} \mathrm{BW} /$ day for 30 days treatment group. This result is in line with research conducted by Tanko et al. (2017) where rutin administration at a dose of 50,100 and $200 \mathrm{mg} / \mathrm{kg}$ BW for 28 days significantly decrease blood glucose levels compared to the control group in diabetic rats (Tanko et al., 2017).

The fasting blood glucose levels in the intervention group of $\mathrm{CP}$ fruit juice at $8 \mathrm{~mL} / 200 \mathrm{~g} \mathrm{BW} /$ day were not significantly differed when compared with the rutin group. These results suggest that $8 \mathrm{~mL} / 200 \mathrm{~g} \mathrm{BW} /$ day of $\mathrm{CP}$ fruit juice has a similar ability with rutin at 10 $\mathrm{mg} / 200 \mathrm{~g} \mathrm{BW} /$ day in lowering fasting blood glucose levels in T2DM rats. It is presumed because CP fruit juice does not only contain rutin compound but also contains other compounds, such as quercetin, caffeic acid, chlorogenic acid and coumaric acid (Pinto et al., 2009). These compounds work synergistically to control hyperglycemia so that they can match rutin ability to decrease fasting blood glucose levels in T2DM. On the other hand, the high level of fasting blood glucose in the diabetic control group may have resulted from the continuous production of ROS feedbacks. This group received standard feed during the 30 days intervention period, but the glucose uptake results in the metabolism of feed in the rats' body decreased by due to the incidence of pancreatic $\beta$-cell damage and insulin resistance in peripheral tissues due to T2DM condition, that leads to increased ROS and blood glucose levels chronically, and no attempt to improve the condition (Matsuda and Shinomira, 2013; Hurrle and Hsu, 2017).

\section{Conclusion}

$\mathrm{CP}$ fruit juice can be a recommended fruit juice for the diabetic condition by reducing TNF- $\alpha$ and fasting glucose blood levels.

\section{References}

Adinugraha, F., Hanson, L. and Yonathan, S. (2018). Potensi beras analog sukun semi instan (Artocarpus communis) sebagai bahan pangan alternatif. Surya Agritama, 7(1), 19-32.

Amalan, V., Vijayakumar, N. and Ramakrishnan, A. (2015). p-Coumaric acid regulates blood glucose and antioxidant levels in streptozotocin induced diabetic rats. Journal of Chemical and Pharmaceutical Research, 7(7), 831-839.

ADA (American Diabetic Association). (2013). Diagnosis and classification of diabetes mellitus. Diabetes Care, 36(1), S67-S64. https:// doi.org/10.2337/dc13-S067

Badawi, A., Klip, A., Haddad, P., Cole, D.E.C., Bailo, B.G., El-Sohemy, A. and Karmali, M. (2010). Type 2 diabetes mellitus and inflammation: Prospects for biomarkers of risk and nutritional intervention. Diabetes, Metabolic Syndrome and Obesity: Targets and Therapy, 3, 173-186. https://doi.org/10.2147/ DMSO.S9089

Chen, L., Deng, H., Cui, H., Fang, J., Zuo, Z., Deng, J., Li, Y., Wang, X. and Zhao, L. (2018). Inflammatory responses and inflammation-associated diseases in organs. Oncotarget, 9, 7204-7218. https:// doi.org/10.18632/oncotarget.23208

Chen, S., Jiang, H., Wu, X. and Fang, J. (2016). Therapeutic effects of quercetin on inflammation, obesity and type 2 diabetes. Mediators of Inflammation, 2016, 9340637. https:// doi.org/10.1155/2016/9340637

Dhungyal, B., Koirala, P., Sharma, C. and Jha, D.K. (2014). Caffeic acid - a potent phytocompound against diabetes mellitus - a review. SMU Medical Journal, 1(2), 152-160.

Frances, D.E., Ingaramo, P.I., Ronco, M.T. and Carnovale, C.E. (2013). Diabetes, an inflammatory process: oxidative stress and TNF- $\alpha$ involved in hepatic complication. Journal of Biomedical Science and Engineering, 6, 645-653. https:// doi.org/10.4236/jbise.2013.66079

Ghasemi, A., Khalifi, S. and Jedi, S. (2014). Streptozotocin-nicotinamide-induced rat model of type 2 diabetes. Acta Physiologica Hungerica, 101 (4), 408-420. https://doi.org/10.1556/ APhysiol.101.2014.4.2

Ghorbani, A. (2017). Mechanisms of antidiabetic effects of flavonoid rutin. Biomedicine and Pharmacotherapy, 96, 305-312. https:// doi.org/10.1016/j.biopha.2017.10.001

Giri, B., Dey, S., Das, T., Sarkar, M., Banerjee J. and Dash, S.K. (2018). Chronic hyperglycemia mediated physiological alteration and metabolic distortion leads to organ dysfunction, infection, cancer progression, and other pathophysiological 
consequences: an update on glucose toxicity. Biomedicine and Pharmacotherapy, 107, 306-328. https://doi.org/10.1016/j.biopha.2018.07.157

Gonzalez, Y., Herrera, M.T., Soldevila, G., GarciaGarcia, L., Fabian, G., Perez-Armendariz, E.M., Bobadilla, K., Guzman-Beltran, S., Sada, E. and Torres, M. (2012). High glucose concentrations induce TNF- $\alpha$ production through the downregulation of $\mathrm{CD} 33$ in primary human monocytes. BMC Immunology, 13, 19. https:// doi.org/10.1186/1471-2172-13-19

International Diabetes Federation. (2019). IDF Diabetes Atlas. $9^{\text {th }}$ ed. Belgium: IDF.

Kumar, S. and Singh, P. (2016). Various techniques for solubility enhancement: an overview. The Pharma Innovation Journal, 5(1), 23-28.

Laily, A.N. and Khoiri, A.N. (2016). Identifikasi senyawa antidiabetes secara in silico pada Carica pubescens Lenne dan K. Koch. El-Hayah, 5(4), 135142. https://doi.org/10.18860/elha.v5i4.3469

Liang, W., Zhang, D., Kang, J., Meng, X., Yang, J., Xue, N., Gao, Q., Han, S. and Gou, X. (2018). Protective effects of rutin on liver injury in type 2 diabetic $\mathrm{db} /$ $\mathrm{db}$ mice. Elsevier: Biomedicine and Pharmacotherapy, 107, 721-728. https:// doi.org/10.1016/j.biopha.2018.08.046

Liu, W., Yin, D., Li, N., Hou, X., Wang, D., Li, D. and Liu, J. (2016). Influence of environmental factors on the active substance production and antioxidant activity in Potentilla fruticosa and its quality assessment. Scientific Reports, 6, 28591. https:// doi.org/10.1038/srep28591

Manzoor, Z. and Koh, Y.S. (2012). Mitogen-activated protein kinases in inflammation. Journal of Bacteriology and Virology, 42(3), 189-195. https:// doi.org/10.4167/jbv.2012.42.3.189

Matsuda, M. and Shinomura, I. (2013). Increased oxidative stress in obesity: implications for metabolic syndrome, diabetes, hypertension, dyslipidemia, atherosclerosis, and cancer. Obesity Research and Clinical Practice, 7(5), 330-341. https://doi.org/10.1016/j.orcp.2013.05.004

Meng, S., Cao, J., Feng, Q., Peng, J. and Hu, Y. (2013). Roles of chlorogenic acid on regulating glucose and lipid metabolism: a review. Evidence-Based Complementary and Alternative Medicine, 2013, 801457. https://doi.org/10.1155/2013/801457

Monteiro, R. and Azevedo, I. (2010). Chronic inflammation in obesity and the metabolic syndrome. Mediators of Inflammation, 2010, 289645. https:// doi.org/10.1155/2010/289645

Mukhopadhyay, P. and Prajapati, A.K. (2015). Quercetin in anti-diabetic research and strategies for improved quercetin bioavailability using polymer-based carriers - a review. RSC Advances, 5, 97547-97562. https://doi.org/10.1039/C5RA18896B

Niture, N.T., Ansari, A.A. and Naik, S.R. (2014). Antihyperglycemic Activity of Rutin in Streptozotocin-Induced Diabetic Rats: An Effect Mediated through Cytokines, Antioxidants and Lipid Biomarkers. Indian Journal of Experimental Biology, 52(7), 720-727.

Niture, N.T., Patil, D.G., Somani, R.S. and Sahane, R.S. (2014) Effect of rutin on diabetic neuropathy in experimental animals. Journal of Natural Product and Plant Resource, 4(4), 1-9.

Ormazabal, V., Nair S., Elfeky, O., Aguayo, C., Salomon, C. and Zuniga, F.A. (2018). Association between insulin resistance and the development of cardiovascular disease. Cardiovascular Diabetology, 17(122), 1-14. https://doi.org/10.1186/s12933-018$0762-4$

Panche, A.N., Diwan, A.D. and Chandra, S.R. (2016). Flavonoids: an overview. Journal of Nutritional Science, 5(47), 1-15. https://doi.org/10.1017/ jns.2016.41

Pinto, M.D.S., Ranilla, L.G., Apostolidis, E., Lajolo, F.M., Genovese, M.I. and Shetty, K. (2009). Evaluation of antihyperglycemic and antihypertension potential of native Peruvian fruits using in vitro models. Journal of Medicinal Food, 12 (2), 278-291. https://doi.org/10.1089/jmf.2008.0113

Rusiah, Satya, M.N. and Wahyudin, A. (2005). Dampak aktivitas pertanian kentang terhadap kerusakan lingkungan obyek wisata dataran tinggi dieng. Pelita, 1(1), 5-11.

Shairibha, S.M.R., Rajadurai, M. and Kumar, N.A. (2014). Effect of p-coumaric acid on biochemical parameters in streptozotocin-induced diabetic rats. Journal of Academia and Industrial Research, 3(5), 237-222.

Simirgiotis, M.J., Caligari, P.D.S. and SchemdaHirschmann, G. (2009). Identification of phenolic compounds from the fruits of the mountain papaya Vasconcellea pubescens A. DC. grown in chile by liquid chromatography-UV detection-mass spectrometry. Food Chemistry, 115(2), 775-784. https://doi.org/10.1016/j.foodchem.2008.12.071

Stolpe, N. and Undurraga, P. (2016). Long term climatic trends in chile and effects on soil moisture and temperature regiments. Chilean Journal of Agricultural Research, 76(4), 487-96. https:// doi.org/10.4067/S0718-58392016000400013

Suryavanshi, S.V. and Kulkarni, Y.A. (2017). NF-кß: A 
potential target in the management of vascular complications of diabetes. Frontiers in Pharmacology, 8, 798. https://doi.org/10.3389/ fphar.2017.00798

Tanko, Y., Salisu, A.I., Mohammed, K.A., Musa, S.A., Jimoh, A. and Yusuf, R. (2017). Antihyperglycaemic effects of rutin on blood glucose, oxidative stress biomarkers, and lipid peroxidation in alloxan-induced hyperglycaemic Wistar rats. Nigerian Journal of Physiological Sciences, 32(1), 91-96.

Volpe, M.N.O., Villar-Deflino P.H., Anjos, P.M.S. and Nogueira-Machado, J.A. (2018). Cellular death, reactive oxygen species (ROS) and diabetic complication. Journal of the Cell Death Differentiation Association, 9, 119. https:// doi.org/10.1038/s41419-017-0135-z

$\mathrm{Xu}, \mathrm{H}$. (2013). Obesity and metabolic inflammation. Drug Discovery Today Diseases Mechanisms, 1(10), 1-2. https://doi.org/10.1016/j.ddmec.2013.03.006

Yahfoufi, N., Alsadi, N., Jambi, M. and Matar, C. (2018). The immunomodulatory and antiinflammatory role of polyphenols. Nutrients, 10, 123. https://doi.org/10.3390/nu10111618

Yang, W.S., Jeong, D., Yi, Y.-S., Park, J.G., Seo, H., Moh, S.H., Hong, S. and Cho, J.Y. (2013). IRAK1/4 targeted anti-inflammatory action of caffeic acid. Mediators of Inflammation, 2013, 518183. https:// doi.org/10.1155/2013/518183

Yusmita, L. and Wijayanti, R. (2018). Pengaruh penambahan jerami nangka (Artocarpus heterophyllus Lam) terhadap karakteristik fruit leather mangga (Mangifera indica L). Jurnal Teknologi dan Industri Pertanian Indonesia, 10(1), 36-41. [In Bahasa Indonesia]. https:// doi.org/10.17969/jtipi.v10i1.10152.

Zhao, Y., Liu, J., Liu, C., Zeng, X., Li, X. and Zhao, J. (2016). Anti-inflammatory effects of p-coumaric acid in LPS-stimulated raw264.7 cells: involvement of NF-kB and MAPK pathways. Medicinal Chemistry, 6(5), 327-330. https:// doi.org/10.4172/2161-0444.1000365 